\title{
Quartz Crystal Microbalance Biosensor for Ergotamine Detection
}

\author{
Miroslav Pohanka \\ Faculty of Military Health Sciences, University of Defence, Trebesska 1575, CZ-500 01 Hradec \\ Kralove, Czech Republic \\ E-mail: miroslav.pohanka@gmail.com
}

doi: $10.20964 / 2020.05 .61$

Received: 3 January 2020 / Accepted: 8 March 2020 / Published: 10 April 2020

Ergotamine is a toxin from ergot fungi. It interacts with various receptors in the organisms including the one for adrenaline, serotonin and dopamine. People can be poisoned by contaminated food but ergotamine is also marketed as a drug for migraine therapy. Because of survey on toxin presence in the food and making countermeasures against them, there are required simple and available methods for ergotamine assay. In this paper, quartz crystal microbalance (QCM) sensor with basic $10 \mathrm{MHz}$ frequency served as a platform for immobilization of an antibody against ergotamine. The ergotamine was determined in a sandwich format using rabbit polyclonal antibody. The assay exerted limit of detection $12.6 \mu \mathrm{g} / \mathrm{ml}$ respectively $9.55 \mu \mathrm{mol} / 1$, it was successfully validated to enzyme-linked immunosorbent assay (ELISA) method and it was not sensitive to interference by ergometrine, albumin or caffeine. The assay was also suitable for measurement of ergotamine in flour and milk that had no significant matrix effect on the results. In a conclusion, the biosensor is a simple and reliable tool for measurement of ergotamine in natural samples. No elaborative steps or techniques are necessary to finish the assay.

Keywords: alkaloid; antibody; biosensor; biorecognition; ergot; ergotamine; immunosensor; food; label free assay; piezoelectric; QCM

\section{$\underline{\text { FULL TEXT }}$}

(C) 2020 The Authors. Published by ESG (www.electrochemsci.org). This article is an open access article distributed under the terms and conditions of the Creative Commons Attribution license (http://creativecommons.org/licenses/by/4.0/). 